\title{
A Brief Analysis of the Formation of Deng Xiaoping's Ideology on Urban and Rural Relations
}

\author{
Ziqing Wei, Yuanqiao Wang \\ School of JiLin Agricultural University, Changchun 130000, China
}

Key words: Xiaoping Deng, urban and rural relations, theoretical origin, practice basis

\begin{abstract}
Xiaoping Deng's thought of urban-rural relations covers the political, economic and cultural aspects, is a set of scientific theoretical system. Xiaoping Deng's thought of urban - rural relations inherited and carried forward the Marxist theory of urban - rural relations and Zedong Mao' s thought of urban - rural relations. And on the basis of practice, formed Deng Xiaoping's thought of urban-rural relationship with Chinese characteristics. Xiaoping Deng's thought of urban - rural relationship is an important theoretical achievement of Marxist theory of urban - rural relations in China.
\end{abstract}

\section{The Connotation of Xiaoping Deng's Thought of Urban - rural Relations}

Urban-rural relationship is a universal relation and interactive relationship between urban and rural interaction, mutual influence and mutual restraint, which is a certain social conditions under the political relations, economic relations, class relations and many other factors in the urban and rural areas of the relationship between the concentrated reflections. ${ }^{[1]}$ The changes in urban-rural relations are mainly the result of the development of productive forces. ${ }^{[2]}$

Xiaoping Deng once pointed out that farmers do not get out of poverty is that China is not out of poverty. In the early days of the founding of the People's Republic of China, the urban and rural sub-system system was given priority to the development of heavy industry and the purchase and sale of agricultural products, and industrial products and agricultural products implement scissors poor policy, resulting in the formation of urban and rural opposition with Chinese characteristics, urban and rural dual structure. With the focus of the country's political struggle to move to economic construction, Xiaoping Deng stand in China's actual situation and sum up the history, as the guide of the Marxist-Leninist Mao Zedong Thought to development the China's urban and rural areas and the history of urban and rural development of a scientific and objective analysis, and as guide of the essence of socialism, which is for the common prosperity of the people, and boldly put forward poverty is not socialism. The ideology of urban and rural areas with Chinese characteristics covers political, economic, cultural and social aspects. The relationship between urban and rural areas with Chinese characteristics from a multi-angle guidance on how to develop new urban and rural economy in the new situation at home and abroad, promote the comprehensive and coordinated development of urban and rural economic society. The ideology of urban and rural areas with Chinese characteristics embodies the rich elements of the theory of urban and rural economic and social development both at home and abroad, and combines with the basic principles and methods of Marxism, breaking through the original boundaries of traditional socialist theory and realizing theoretical innovation. Facts eloquently prove that the relationship between urban and rural areas with Chinese characteristics is a set of scientific theoretical system, is the Marxist theory of urban and rural areas of the important theoretical results, which will be timeless with the progress of the times, and will be brilliant in the long river of history. 


\section{The theoretical origins of Xiaoping Deng's thought on the relationship between urban and rural areas}

Marx once wrote, the middle ages (the Germanic era) departed from the historical stage of the country, and then its further development was carried out in urban and rural opposition; the modern history is the urbanization of the countryside, rather than the urbanization of the city as in ancient times. ${ }^{[3]}$ Marx pointed out that the relationship between urban and rural areas from the initial opposition to the development of the relationship, which indicates the direction and development of urban-rural relations. In the development of the relationship between the opposing relationship to the development of a decisive role in the development of productive forces and improve. However, Marx pointed out that the modern history of rural urbanization, its essence is the continuous development and improvement of rural productivity, productivity development and improvement at the same time to the city continue to move closer, that is, urban and rural integration.

Zedong Mao has once clearly pointed out that the Chinese proletariat should understand: Although they are the most conscious and the most organized class, but if only a class of their own, they cannot win. But to win, they must unite all possible revolutionary classes and classes in a variety of situations, and organize the united front of the revolution. ${ }^{[4]}$ Zedong Mao clearly recognized that the great power of the workers 'and peasants' alliance was the backbone of the Chinese revolution and construction. The united front of the workers' and peasants not only consolidated the revolutionary united front, but also strengthened the connection between the countryside and the city and promoted the development of urban-rural relations.

After the Cultural Revolution, Xiaoping Deng defended the country's work by the class struggle to shift to economic construction. Xiaoping Deng clearly pointed out: The rural population accounts for $80 \%$ of our population, rural instability will lead to instability in the political situation, farmers do not get out of poverty, and that is, our country is not out of poverty. From the reality of China, we must first solve the rural problems. China has 80 percent of the population living in rural areas, China's stability and instability will first look at this 80 percent stable and unstable. The city was so beautiful, but there is not stable basis for rural areas is not enough. Xiaoping Deng attaches great importance to the basic role of agriculture in the construction of our country, which is related to political stability and economic development. Deng Xiaoping summed up the history and combined with the actual situation of China's urban and rural areas; far-sighted that development is the last word and pointed out the direction of the people's struggle and only development is the fundamental way of developing urban and rural areas. Poverty is not socialism, and development slow is not socialism either, common prosperity and other ideas that urban and rural development can make the people's living standards improve the people, which is the socialist superiority and the essence of socialism embodied in China's socialist construction is also the guiding ideology of handling urban and rural relations.

\section{The practical foundation of Xiaoping Deng's thought on the relationship between urban and rural areas}

\subsection{The need for chaos after the Cultural Revolution.}

The extreme left mistakes of the decade of the Cultural Revolution have led to the stagnation and wandering state of Chinese society and the rigidity of thought. To be frank, most farmers are in a very poor situation without reform, and it is very difficult. ${ }^{[5]}$ Therefore, in 1978, the Third Plenary Session of the Eleventh Central Committee established our fundamental political line, the four modernizations and efforts to develop social productive forces as an overriding central task. With the support of Enlai Zhou, Xiaoping Deng resumed the post of Vice Premier of the State Council in 1973. In 1975, Xiaoping Deng began to rectify the turmoil caused by the chaos of the decade and began to carry out comprehensive reform of the whole country. This kind of reform began in the rural areas. In Xiaoping Deng's thought of urban-rural relationship, agriculture was in the basic position of the national economy, while the peasants accounted for 80 percent of the total population, and the living 
standards of peasants directly responded to the development level of our country. After the Cultural Revolution, it was a matter of course to turn out political ideology and economic construction. In the field of economic construction in the chaos, rural reforms bear the brunt of the reform. Xiaoping Deng is concerned about the development of urban and rural areas and the people. At the turning point of history, the development of society needs the guidance and guidance of Xiaoping Deng's thought.

\subsection{Xiaoping Deng's urban - rural thought comes from the experience of the masses in the process of reform}

The people are the creators of history and the great practitioners of reform and opening up. After the Third Plenary Session of the 11th, reform and opening up from the economic side, and first of all began from the rural areas. ${ }^{[6]}$ In the winter of 1978, 18 villagers in Xiao Gang Village, who pressed under the red handprint, risking the "big contracting" receipt of the opening of China's rural reform as a whole and even the reform of the curtain. China's reform and opening up began in the exploration began. The villagers of Xiao gang village have created the spirit of "dare to do, dare to do it". The village of Xiao gang was also made a leap from the humble village to the first village in the reform of rural area in China. Deng Xiaoping also bluntly pointed out in 1987, "of course, not everyone approves of reform. There are two provinces, one is Sichuan province, and that is my hometown. One is Anhui province, which was the host of comrade wan li. ${ }^{[7]}$ it is because of the remarkable results achieved by the courageous Villagers in Xiao gang village. Those provinces and regions with a wait-and-see attitude have not kept pace with the reform in the first two years of the reform. The central policy is to wait for them, and let the facts go to them. ${ }^{[8]}$ In the wave of reform and opening up, WuRenbao created Huaxi Village; LuGuanqiu built up the factory of "Xiao Shan Universal joint"; LiJingwei created the myth of the "Jian Li Bao"; The Haier group led by zhang ruimin has developed into the first brand of household appliances in China. Panning created the first double-door refrigerator in the town of Rong Gui in ShunDe, Guang Dong province. The enterprises that affected or changed the history of Chinese enterprises are all township enterprises. Deng xiaoping pointed out: "in the rural reform, the biggest unexpected harvest is the development of township enterprises. They suddenly make a variety of industries, make commodity economy, and make all kinds of small businesses. They suddenly rise as a new force." ${ }^{[9]}$ Deng xiaoping attached great importance to the practice of the people and summarized it in a timely manner, thus forming a urban-rural relationship with Chinese characteristics and figuring out a way to develop the urban and rural development suited to China's actual conditions.

\section{References}

[1]. Li quan. A Review Of The Relationship Between Chinese And Foreign Countries. Social sciences press, gansu. 2005. P. 207-212.

[2]. Xu rongan.China's new urban-rural relationship. chongqing press. 1988. Page 74.

[3]. The Complete Works of Marx and Engels.Vol. 46, People's Publishing House, 1960. p. 480.

[4]. Selected Works of MAO Zedong.volume 2, People's Publishing, and 1991:645.

[5]. Deng Xiaoping's Selected Works. Volume III [M]. Beijing: People's Publishing House, 1993: 237.

[6]. Deng Xiaoping's Selected Works. Volume III [M]. Beijing: People's Publishing House, 1993: 238. 